\title{
DID GOD CREATE CHAOS? \\ UNRESOLVED TENSION IN GENESIS 1:1-2 \\ Robin Routledge
}

\begin{abstract}
Summary
OT writers appear to use imagery found in other Ancient Near Eastern texts and portray creation as God's victory over, and transformation of, 'chaos'. This is sometimes associated with the expression תדהוי וזבדו (tohu wabohu), translated 'formless and empty', in Genesis 1:2 (NIV). Recent interpretations of Genesis 1:1-2 imply that this chaos existed before God began his creative work. A more traditional view is that Genesis 1:1 implies that the cosmos was created out of nothing. This paper argues that Genesis 1 does point to God as the originator of all things, and also to creation as an ordering of chaos, with little attempt to resolve that tension. More important is the theological significance of holding these ideas side by side. One points to the transcendence, power and pre-existence of God. The other understands creation as a process, in which chaos, not unbeing, is the opposite of creation. This allows the possibility that chaos may return as a result of human sin (e.g. in the flood), and that new life and hope may be brought to desperate situations such as the exile (also portrayed as a return to chaos-e.g. in Jeremiah 4:23).
\end{abstract}

\section{Creation out of Chaos}

The Chaoskampf motif, which depicts creation as a battle between the Creator god and the forces of chaos, represented by the primaeval waters (and the monsters associated with them), is seen, particularly, in the Babylonian creation myth, Enuma Elish. This describes how Marduk, the storm god, defeated Tiamat, the primaeval salt water ocean, and divided her body to 'create' the earth and the heavens. The Ugaritic myth, Baal and the Sea, contains a similar motif: with the god 
Baal defeating Yam who, again, represents the (chaotic) sea. This does not include a detailed account of creation and many scholars do not regard it as a creation myth. ${ }^{1}$ However, there is a suggestion that Baal's victories over Yam and later over Mot (Death) result in order being brought to the cosmos, including pouring 'well-being out into the earth, calmness into the fields', ${ }^{2}$ and sending rain in its season. ${ }^{3}$ This, together with the acknowledgement of Baal's kingship and the building of a temple, which may also have cosmological significance, ${ }^{4}$ has led some to the view that there is creation of sorts in the Ugaritic text. ${ }^{5}$

It has been widely acknowledged that there are echoes of these Ancient Near Eastern myths in the Old Testament. ${ }^{6}$ Some passages

1 E.g. D. J. McCarthy, “"Creation” Motifs in Ancient Hebrew Poetry', $C B Q 29$ (1967): 393-406.

2 A. Herdner, Corpus des tablettes en cunéiformes alphabétiques découvertes à Ras Shamra-Ugarit de 1929 à 1939 (Mission de Ras Shamra, 10; Paris: Imprimerie Nationale; Geuthner, 1963) (CTA) 3, iii 17-18; see The Context of Scripture Volume One: Canonical Compositions from the Biblical World, ed. William W. Hallo (Leiden: Brill, 1997): 251.

3 CTA 4, v. 69; see Hallo, Context of Scripture 1, 259.

4 See, e.g. G. K. Beale, The Temple and the Church's Mission: A Biblical Theology of the Dwelling Place of God (Leicester: Apollos; Downers Grove: InterVarsity Press, 2004); R. E. Clements, God and Temple (Oxford: Basil Blackwell, 1965); Jon D. Levenson, Creation and the Persistence of Evil: The Jewish Drama of Divine Omnipotence (Princeton: Princeton University Press, 1988): 78-99; John H. Walton, The Lost World of Genesis One: Ancient Cosmology and the Origins Debate (Downers Grove: IVP, 2009): 38-107; see also Loren R. Fisher, 'Creation at Ugarit and in the Old Testament', VT 15 (1965): 313-24; Loren R. Fisher, 'From Chaos to Cosmos', Encounter 26.2 (1965): 183-97.

5 See, e.g. Fisher, 'Chaos to Cosmos'; Jakob Grønbæk, 'Baal's Battle with Yam-A Canaanite Creation Fight', JSOT 33 (1985): 27-44; see also John N. Day, 'God and Leviathan in Isaiah 27:1', BibSac 155 (1998): 423-36; John N. Day, God's Conflict with the Dragon and the Sea: Echoes of a Canaanite Myth (Cambridge: Cambridge University Press, 1985): 7-18. John Walton argues that few ANE texts link theomachy with cosmogony (Enuma Elish being one of the exceptions), and that Baal's conflict with Yam is about the struggle for political power among the gods rather than Chaoskampf; see John H. Walton, 'Creation in Genesis 1:1-2:3 and the Ancient Near East: Order out of Disorder after Chaoskampf', CTJ 43 (2008): 48-63 [49-51]. Walton is right to argue that the use of the term 'Chaoskampf' needs to be more nuanced. However the distinctions he notes between different kinds of theomachy in ANE texts are not always as clear as he suggests. Thus the conflict between Baal and Yam is not only about power among the gods but also has implications for the peace and wellbeing of the earth and for the ordering of the seasons. Temple building may also have significant implications for bringing order to creation, as Walton himself points out ('Creation', 60-61), though he seems reluctant to apply this in the case of Baal. In his later work, Lost World, he allows that there is, 'perhaps', creation material in the Baal cycle (p. 29).

6 See further, e.g. B. W. Anderson, Creation versus Chaos: the Reinterpretation of Mythical Symbolism in the Bible (New York: Association Press, 1967); B. W. 
refer to Leviathan (Job 3:8; 41:1; Ps. 74:14; 104:26; Isa. 27:1), who is generally thought to be the equivalent of Lotan in the Baal myth, ${ }^{7}$ where the monster is either identified with Yam or named as one of Yam's cohorts. ${ }^{8}$ Rahab (Job 26:12; Ps. 89:10; Isa. 51:9) may be another name for Leviathan, ${ }^{9}$ though the term does not appear outside the Old Testament. There are also references to תַתנּניך (tannin) a more general term sometimes translated 'sea monster' or 'dragon' (e.g. Ps. 74:13; Isa. 27:1), and this, too, is associated with Yam in the Baal myth. The occurrence of these terms in passages that describe or allude to God's creative activity suggests a version of the Chaoskampf motif in the Old Testament-though one that has been given a substantially new meaning and significance. ${ }^{10}$ One important aspect of this is the reapplication of mythological imagery to the events of Israel's history. For example, the waters of the deep associated with creation are taken to symbolise the waters of the Red Sea (e.g. Ps. 74:12-17; 77:16-19;

Anderson, From Creation to New Creation: Old Testament Perspectives (Overtures to Biblical Theology; Minneapolis: Fortress Press, 1994); T. E. Fretheim, God and World in the Old Testament: A Relational Theology of Creation (Nashville: Abingdon Press, 2005). Though note, also, D. Tsumura, Creation and Destruction-A Reappraisal of the Chaoskampf Theory in the Old Testament (Winona Lake: Eisenbrauns, 2005); Rebecca S. Watson, Chaos Uncreated: A Reassessment of the Theme of 'Chaos' in the Hebrew Bible (BZAW, 341; Berlin: de Gruyter, 2005).

7 Lotan is described in the Baal myth as 'the fleeing serpent ... the twisting serpent, the close-coiling one with seven heads' (CTA 5, i 1-3); see Hallo, Context of Scripture 1,265 . This appears to be echoed in the description of Leviathan as a 'twisting serpent' in Isaiah 27:1. Lotan's seven heads may be reflected in Ps. 74:14-'you crushed the heads of Leviathan'. Emerton notes the linguistic link between the Hebrew and Ugaritic terms, though argues that ltn should be vocalised as litanu rather than lotan; see J. A. Emerton, 'Leviathan and ltn: the Vocalization of the Ugaritic Word for the Dragon', VT 32.3 (1982): 327-31.

8 Following his victory over Yam, Baal claims: 'I have 'smitten Ilu's beloved, Yammu, have finished off the great god Naharu. I have bound the dragon's? jaws, have destroyed it, have smitten the twisting serpent, the close-coiled one with seven heads' (CTA 3, iii 32-iv 51); see Hallo, Context of Scripture, 1: 252. This includes the same terms that, as we have already noted, are used to describe Lotan. These may all be references to Yam; or may describe the defeat of Yam with his allies; see, e.g. Day, 'God and Leviathan', 427-29; Day, God's Conflict, 14-15.

9 Leviathan is described as 'the gliding serpent' in Isa. 27:1; and this expression occurs also in relation to Rahab in Job 26:13. See also 'Monsters' in The Dictionary of Biblical Imagery, ed. Leland Ryken, James C. Wilhoit, Tremper Longman III (Nottingham: IVP, 1998): 562-65 [571].

10 For further discussion and bibliography, see Robin Routledge, Old Testament Theology: A Thematic Approach (Nottingham: Apollos, 2008; Downers Grove: IVP Academic, 2009): 129-30. 
Isa. 51:9-10); ${ }^{11}$ and the nations that threaten Israel are sometimes depicted as chaos monsters. Because of the link between the waters of chaos and the Red Sea, Egypt is frequently represented in this way: as תַתִִּיך

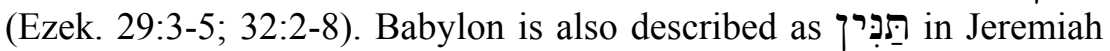
51:34. Leviathan in Isaiah 27:1 may refer to a particular enemy, though it may better be seen as human power in opposition to God. A further example of the waters representing Israel's historical enemies may be in Psalm 46, where the roaring waters in verse 3 are paralleled with the uproarious nations in verse 6 .

Following Gunkel, the creation narrative in Genesis 1 has been frequently linked with Enuma Elish; ${ }^{12}$ though some have suggested an Ugaritic or an Egyptian background. ${ }^{13}$ Gunkel himself claimed that the Genesis 1 account is a Judaicised version of Enuma Elish. ${ }^{14}$ However, while there may be enough points of similarity to suggest that the writer of Genesis 1 knew the Babylonian myth and used some of its imagery, it is widely recognised that there is nothing to indicate dependence. The conflict motif and ultimate exaltation of the creator god which is a central feature of Enuma Elish is missing from Genesis 1 (though not necessarily from other occasions where the Chaoskampf motif occurs); and David Tsumura has argued, convincingly, against Gunkel's claim that (tehom) ('deep'), in Genesis 1:2 is a reference to the Babylonian 'Tiamat'. ${ }^{15}$

11 See also, P. C. Craigie, 'The Poetry of Ugarit and Israel', TynBul 22 (1971): 3-31, esp. 19-26. Craigie notes parallels between the 'Song of the Sea' (Exod. 15:1-18) and the Ugaritic Baal myth-which, following Fisher ('Creation'), he takes as a creation story.

12 Hermann Gunkel, Schöpfung und Chaos in Urzeit und Endzeit (Göttingen: Vandenhoeck \& Ruprecht, 1895), tr. K. William Whitney, Jr., as Creation and Chaos in the Primeval Era and the Eschaton: A Religio-Historical Study of Genesis 1 and Revelation 12 (Grand Rapids: Eerdmans, 2006): 3-111.

13 Day argues that Genesis 1 is not related to Enuma Elish, but instead is dependent on the language of Ps. 104, which reflects Ugaritic mythology (God's Conflict, 51-53); Levenson also points to similarities between Genesis 1 and Psalm 104 (Creation, 5359), though continues to link Genesis 1 with Enuma Elish. Gordon H. Johnston, 'Genesis 1 and the Ancient Egyptian Creation Myths', BibSac 165 (2008): 178-94, points to structural links with Egyptian creation texts.

14 Gunkel, Creation and Chaos, 82. Gunkel notes three steps in the process: ' 1 . The Babylonian myth is transferred to Israel; 2. There it loses many of its mythological elements and nearly all of its polytheistic elements; 3 . In Genesis 1 it is, as far as it was possible, completely Judaized'.

15 David T. Tsumura, The Earth and the Waters in Genesis 1 and 2: A Linguistic Investigation (JSOTSup, 83; Sheffield: Sheffield Academic Press, 1989), rev. and expanded in Tsumura, Creation and Destruction. 
However, whilst תרזור cannot derive from Tiamat, there appears to be general agreement that it is from the same root, ${ }^{16}$ and so may have been included as an intentional allusion to the Babylonian myth; though, significantly, in the Genesis narrative תזה is not given divine status nor even personified. The reference, in the same verse, to the תזהו וָבהוּ (tohu wabohu) which the NIV translates, 'formless and empty', has been widely taken to refer to a primordial chaos, which is then transformed by God. This, again, appears deliberately to recall Ancient Near Eastern mythology; though the absence of a conflict motif in Genesis 1 suggests that, as with תמוֹ, chaos is passive rather than in active opposition to the Creator.

One explanation for these points of contact is that the Genesis account is polemic against the theology of Enuma Elish and other Ancient Near Eastern creation myths. ${ }^{17}$ However, whilst there may be polemical elements in Genesis 1, the allusions are too indirect for that to be the primary concern of the passage, and it seems unlikely that a polemical account of creation would retain the idea of primordial chaos, even in a non-mythical form. ${ }^{18}$ More likely, the narrator in Genesis 1 is setting out an authentic and distinctive creation theology, but in so doing is willing to use familiar mythological imagery to present important ideas that might not easily be expressed in other ways.

Tsumura wants to minimise the link with Ancient Near Eastern ideas, and argues that the expression תדהו רָבדהו chaos but points, rather, to a world that is at first only uninhabited and unproductive. ${ }^{19}$ Cassuto refers to 'an undifferentiated, unorganized, confused and lifeless agglomeration, ${ }^{20}$ and this, too, seems to suggest a

\footnotetext{
16 See, e.g., Victor P. Hamilton, The Book of Genesis Chapters 1-17 (NICOT; Grand Rapids: Eerdmans, 1991): 110-11; Gordon J. Wenham, Genesis 1-15 (WBC, 1; Milton Keynes: Word UK, 1991): 16; Claus Westermann, Genesis 1-11: A Continental Commentary (Minneapolis: Fortress, 1994): 105.

17 See, e.g., Gerhardt F. Hasel, 'The Significance of the Cosmology in Genesis 1 in Relation to Ancient Near Eastern Parallels', AUSS 10 (1972): 1-20; Gerhardt F. Hasel, 'The Polemical Nature of the Genesis Cosmology', EQ 46.2 (1974): 81-102.

18 'Non-mythical' seems better than 'demythologised' since the latter suggests that the writer began with Enuma Elish and changed elements of it (as in Gunkel's view). In my view the Genesis creation account is distinctive - though with intentional echoes of the Babylonian myth.

19 Tsumura, Creation and Destruction, 9-35, esp. 33-35.

20 Umberto Cassuto, A Commentary on the Book of Genesis, Part I (Jerusalem: Magnes Press, 1961): 23.
} 
more neutral understanding; as does Walton's view, that Genesis 1:2 refers 'primarily to a nonfunctional and nonproductive condition'. ${ }^{21}$

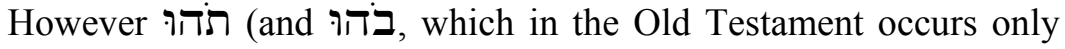
alongside neutral term. It refers to the trackless desert wasteland that is threatening as well as empty (Deut. 32:10; Job 6:18; 12:24); and to the desolation that follows divine judgment (Isa. 24:10; 34:11; 40:23), including the condition of Judah in exile (Isa. 45:18; Jer. 4:23). In other passages תדו is also associated with empty words that deprive the righteous of justice (Isa. 29:21; 59:4); and with the worthlessness of the nations and their idols (Isa. 40:17; 41:29; 44:9). The term here may be closer to having a neutral meaning; however the context in which it is used remains negative. תדור may be interpreted neutrally in Job 26:7He spreads out the northern skies over empty space (תחור) but it is difficult to take this as a significant counter example, since it is followed by what appears to be a clear example of the Chaoskampf motif (vv. 10-13). These associations suggest that תהו רָבדהו in Genesis $1: 2$ is to be seen, at best, as negative and undesirable. ${ }^{22}$

Levenson wants to go further. ${ }^{23}$ In his view, chaos is more sinister. It is opposed to God as his 'primal challenger', ${ }^{24}$ and if not reined in by

21 Walton, 'Creation', 58; see also Walton, Lost World, 48-50. Walton argues that בָּר (bara') in Gen. 1 describes the creation of functionality rather than the origin of material, and thus the starting point in Gen. 1:2 is non-functionality rather than chaotic matter. However his claim that within a functional ontology' ('Creation', 58; see also Lost World, 38-46) is questionable. This may be part of what is involved, but to insist that בָּר ָד does not refer to the creation of material requires a selective reading of the evidence. Walton allows that primeval waters are a way of referring to non-existence 'in the functionally oriented ancient world' (Lost World, 49). Walter Eichrodt, Theology of the Old Testament (vol. 2 ; London: SCM, 1967): 101-106, expresses a similar view, suggesting that formlessness in Gen. 1:2 is the writer's way of describing that 'nothingness' from which God created. However, this does not adequately account for the combat motif in several ANE texts which seems to imply something more negative than nonexistence. Walton does acknowledge the adversarial nature of the waters in ANE creation accounts (Lost World, 52), though that does not seem to figure in the rest of his discussion. I agree with Walton that Gen. 1 needs to be viewed as ancient cosmology; written in terms that Israel (as part of the ancient world) understood. As such it is a theological, rather than a literal or scientific, account of creation. It is the negative aspect of the pre-creation state (which I refer to as 'chaos') that Walton's view does not fully deal with, and that leads to the tension discussed in this article.

22 See also Bruce K. Waltke, An Old Testament Theology: An Exegetical, Canonical and Thematic Approach (Grand Rapids: Zondervan, 2007): 181, n. 16; Bruce K. Waltke, 'The Creation Account in Genesis 1:1-3': III-The Initial Chaos Theory and the Pre-creation Theory', BibSac 132 (1975): 216-28 [219-20].

23 Levenson, Creation, esp. 14-25. 
God it will run amok and destroy the order of creation. Though, as Levenson also notes, this idea of chaos as the enemy of God has been largely purged from the account in Genesis 1. However, Levenson seems to read too much into the Chaoskampf imagery of the Old Testament, which is used generally to emphasise, not the continuing threat posed by chaos, but God's victory over it (e.g. Job 38:8-11; 41:1-11; Pss. 74:12-17; 104:6-9; Isa. 27:1). Chaos may return; but that, too, is under God's control and takes place at his command. תחהו רָבדהוּ , represents the opposite of created order, and points to a scene of utter desolation which needs to be transformed by God's creative activity.

\section{Genesis 1:1-2: Where Did Chaos Come From?}

Accepting that תהוּ רָבדהו refers to a primordial chaos which God then transforms, the question arises: where, according to the Old Testament writers, did that chaos originate? This question has, in part, influenced the discussion of the translation of Genesis $1: 1$ and the way it relates to the following verses. It is not my intention to discuss in detail the various permutations; that ground has been, and continues to be, well covered. ${ }^{25}$ The key issue from that discussion, for the purposes of this paper, is whether or not the state of chaos was already present when God began the work of creation.

It is increasingly common to read Genesis $1: 1$ as a temporal statement dependent either on verse 2-when God began to create the heavens and the earth the earth was a formless void (so NRSV mg.)or (less commonly) on verse 3-when God began to create the heavens

24 Levenson, Creation, 16.

25 See, e.g. Cassuto, Genesis 1, 19-23; Hamilton, Genesis 1-17, 103-117; Robert D. Holmstedt, 'The Restrictive Syntax of Genesis i 1', VT 58 (2008): 56-67; William R. Lane, 'The Initiation of Creation', VT 13 (1963): 63-73; E. A. Speiser, Genesis: Introduction, Translation and Notes (AB, 1; New York: Doubleday, 1964): 3-13; Bruce K. Waltke, 'The Creation Account in Genesis 1:1-3': I-Introduction to Biblical Cosmogony', BibSac 132 (1975): 25-36; Bruce K. Waltke, 'The Creation Account in Genesis 1:1-3': II-The Restitution Theory', BibSac 132 (1975): 136-44; Bruce K. Waltke, 'Creation Account III'; Bruce K. Waltke, 'The Creation Account in Genesis 1:1-3': IV-The Theology of Genesis 1', BibSac 132 (1975): 327-42; Bruce K. Waltke, 'The Creation Account in Genesis 1:1-3': V-The Theology of Genesis 1 continued', BibSac 133 (1976): 28-41; Wenham, Genesis 1-15, 11-13; Westermann, Genesis 1-11, 78, 93-102. See also John Goldingay, Old Testament Theology 1: Israel's Gospel (Downers Grove: IVP Academic; Milton Keynes: Paternoster, 2003): 75-83. 
and the earth ... God said - with verse 2 in parentheses (now the earth was formless and empty). In both these cases, verse 2 is generally understood to describe the chaotic state that obtained before any of God's creative activity took place.

These readings take the opening of the verse, כִּרִ (bere'shit) as a construct ('in-[the]-beginning-of'), because of the absence of the definite article. However, the grammatical difficulty of having a

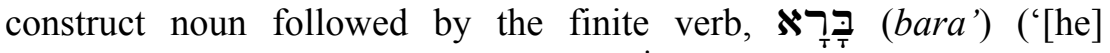

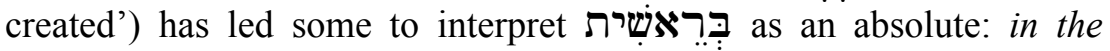
beginning. The NRSV retains the temporal dependence on verse 2 -in the beginning when God created the heavens and the earth, the earth was a formless void. Other translations take verse 1 as an independent summary statement: in the beginning God created the heavens and the earth ${ }^{26}$ with verse 2 as a circumstantial clause - the earth being formless and empty - again describing the state of chaos that existed when God set about his creative work.

The idea that verse 1 is temporally dependent on what follows has received recent support from Holmstedt. ${ }^{27} \mathrm{He}$ acknowledges the

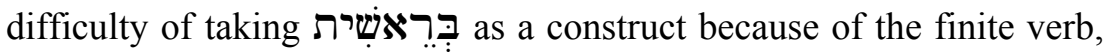
$\aleph \underset{\tau}{ } \underset{7}{\top}$, though notes that in relative clauses the head may sometimes be in the construct, with the relative term omitted-leaving the construct adjacent to a finite verb. He claims that Genesis 1:1 is an example of this kind of construction, with the construct relative clause not the verb; and he suggests the translation: 'in the initial period that/in which God created the heavens and the earth'. Holmstedt argues further that when the head is in the construct, the relative clause is always restrictive, defining this particular 'beginning' over against other possible beginnings; and he maintains that this rules out the possibility that בִּרִ refers to the single absolute beginning of all time.

Taking Genesis 1:1 as an unmarked relative clause does remove traditional difficulties associated with the verse. However it may not be as fatal to the idea of an absolute beginning as Holmstedt claims. If Genesis $1: 1$ is a restrictive relative clause, the restricting clause takes

26 For discussion of the interpretation of בִּראטגשית in this context, see, e.g. Cassuto, Genesis 1, 19-20; Hamilton, Genesis 1-17, 103-108; Lane, Initiation of Creation, 6069; Waltke, 'Creation Account III', 222-25; Wenham, Genesis 1-15, 12; Westermann, Genesis 1-11, 95-98.

27 Holmstedt, 'Restrictive Syntax'. 
on an increased significance as that which defines the 'beginning': this is the beginning of the process in which 'God created the heavens and the earth'. There may be a polemical element here too: this is the beginning in which God (not Marduk, Baal nor any other Ancient Near Eastern deity) created the heavens and the earth! According to Holmstedt, בּּר in 1:1 refers to an initial stage of the process of creation, and not to an absolute beginning. ${ }^{28}$ However, the construction does indicate a specific beginning, which is defined in relation to God's creative work: 'in the beginning that/in which God created the heavens and the earth ...'; and could be taken, therefore, to indicate a point before which nothing else existed - and that may not be too far from the idea of an absolute beginning.

Holmstedt goes on to argue that this construction implies that Genesis $1: 1$ is temporally dependent either on verse 2 or on verse 3, which would again favour the idea of pre-existent chaos. However, it is not linked directly with either of those verses, and might be understood to set a more general temporal framework for the account of creation in Genesis 1 as a whole. The description of chaos in verse 2 might then be taken as part of the account of God's creative activity, rather than the setting for it.

A more traditional view again takes verse 1 to be an independent statement, referring to an absolute beginning; but argues that the state of chaos described in verse 2 is not pre-existent. Rather, it is the result of an initial act of creation, ${ }^{29}$ which is then transformed by subsequent creative acts. One version of this view is that verse 1 describes the creation of this chaos. ${ }^{30}$ It seems more likely, though, that 'the heavens and the earth' as a compound expression refers (as in Gen. 2:1, 4) to the ordered cosmos rather than to a disordered preliminary stage in its creation. ${ }^{31}$ Genesis 1:1 would then be a summary statement which emphasises (also taking account of the merism 'heavens and earth')

28 Holmstedt, 'Restrictive Syntax', 66.

29 See Donald E. Gowan, Genesis 1-11: From Eden to Babel (ITC; Grand Rapids: Eerdmans; Edinburgh: Handsel Press, 1988): 18; John E. Hartley, Genesis (NIBC; Peabody: Hendrickson; Carlisle: Paternoster, 2000): 41.

30 See, e.g. Alexander Heidel, The Babylonian Genesis (2nd edn; Chicago: University of Chicago Press, 1963): 90-91; Wenham, Genesis 1-15, 13.

31 See, e.g. Waltke, 'Creation Account III', 217-19; however, cf. Wenham, Genesis $1-15,13$. If Gen. 2:1 forms an inclusio with Gen. 1:1; that too suggests that they both refer to the completed cosmos. 
that God is the sole creator of everything, ${ }^{32}$ and the detail of what that means is then set out in the rest of the chapter. In support of this view, Wenham notes that the direct article is frequently absent from temporal phrases, and this does not, therefore, imply that בּרִ construct state. He suggests, further, that Isaiah 46:10 may refer to an absolute beginning; as does the similar expression in Proverbs 8:23. ${ }^{33}$

I lean towards the view that Genesis $1: 1$ is an independent summary statement: 'in the beginning, God created the heavens and the earth'. Though even if it is a restrictive relative clause, 'in the beginning that God created the heavens and the earth', which sets the temporal framework for all that follows, it still may be taken to refer to the very beginning of creation and thus to point to God as the sole creator of all that exists.

This has sometimes been articulated as creatio ex nihilo, ${ }^{34}$ though that is too precise, and too abstract a theological category for the Old Testament writers, and does not find unambiguous expression until at least 2 Maccabees 7:28 - look at the heaven and the earth and see everything that is in them, and recognize that God did not make them out of things that existed (cf. Heb. 11:3), and probably even later. ${ }^{35}$ Nevertheless, the idea of a god or gods who exist before anything else and from whom all things ultimately come was common in Ancient Near Eastern cosmogony; and that appears to be reflected in Old Testament passages which suggest that God is pre-existent and eternal (e.g. Ps. 90:2), and that he called everything into being (e.g. Ps. 148:1-

32 See also Rolf Rendtorff, The Canonical Hebrew Bible: A Theology of the Old Testament (Leiden: Deo, 2005): 13-14.

33 Wenham, Genesis 1-15, 12.

34 Those who argue that Gen. 1 supports the doctrine of creation ex nihilo include Heidel, Babylonian Genesis, 89; Gerhard von Rad, Genesis (OTL, rev. edn; London: SCM, 1972): 49-51; Brevard S. Childs, Myth and Reality in the Old Testament (Studies in Biblical Theology, 2nd edn; London: SCM, 1962): 40-42. Van Leeuwen argues that the verse points to an 'absolute beginning of the universe', and though it does not point explicitly to creatio ex nihilo, 'the intention of this later, more abstract theological formulation (2 Macc. 7:28) is not false to Genesis 1'; see Raymond C. Van Leeuwen, 'בראי in NIDOTTE 1: 728-35 [732]. Eichrodt also argues, both on linguistic and

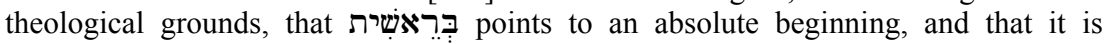
incontestable that 'creatio ex nihilo thereby enters the picture'; see Walter Eichrodt, 'In the Beginning: A Contribution to the Interpretation of the First Word in the Bible' in Creation in the Old Testament, ed. Bernhard W. Anderson (London: SPCK; Philadelphia: Fortress, 1984): 65-73 [72].

35 Gerhard May, Creatio ex Nihilo (Edinburgh: T \& T Clark, 1994): 6-7, suggests that the reference in 2 Macc. 7:28 needs to treated with caution and argues that the idea may be traced, rather, to Basilides in the Second Century AD. 
7; Prov. 8:22-27). Significantly, Psalm 104:26 includes Leviathan among what God has created; ${ }^{36}$ Genesis 1:21 refers also to his creation of תַנְּרנִם (tanninim) and in Psalm 148:7 these sea monsters as well as the 'ocean depths' (תינהמות) are invited to praise YHWH as part of his created order. This last verse may refer to the oceans and the great creatures within them; ${ }^{37}$ however, the language is also likely to recall chaos imagery. ${ }^{38}$ One suggestion is that this, again, is polemic against Ancient Near Eastern creation myths. It seems unlikely, though, that the primary purpose of such a positive hymn of praise would be polemical. ${ }^{39}$ However there may be an ironic element, which sets creation traditions against the background of YHWH's glory and final authority and asserts that even those things that Ancient Near Eastern myths treat as primal were created by YHWH!

This may be particularly significant against the background of Enuma Elish. The Mesopotamian myth begins with Apsu and Tiamat as the progenitors of everything else. ${ }^{40}$ The opening statement of Genesis 1, which has some similarities with the beginning of Enuma Elish, emphasises instead, the role of God as creator; and it seems at least possible that that provides a further, intentional, contrast between God and the Babylonian Ur-deities as the one from whom everything

36 Levenson suggests that Ps. 104 represents a development from the idea of chaos, represented by Leviathan, being opposed to, and defeated by, God; here 'the terrifying monster of Job 40 has been emasculated into a toy' (Creation, 54). He sees Gen. 1 as a further stage in this demythologising: 'there Leviathan has been purged-almost, that is' (Creation, 54). In this Levenson sees the account of creation in Gen. 1, which he describes as 'creation without opposition', as an attempt to suppress the mythological combat motif (unsuccessfully, as evidenced by its later development in apocalyptic writings). Part of my argument in this article is that a diachronic explanation of different ideas of creation is unnecessary. The canonical text sets different models side by side, not preferring one or another, but holding them in tension-because each reflects an important theological idea.

37 E.g. A. A. Anderson, Psalms, vol. 2 (NCB; London: Oliphants, 1972): 950; Leslie C. Allen, Psalms 101-150 (WBC, 21; Waco: Word, 1983): 316.

38 Weiser suggests that 'the creation story with its tradition of the combat of the gods against the powers of chaos forms the background of this psalm'; see A. Weiser, The Psalms (OTL; London: SCM, 1962): 838; VanGemeren also notes the link with ANE mythology, pointing to the psalmist's 'polemical concern'; see Willem A. VanGemeren, 'Psalms' in The Expositor's Bible Commentary, ed. Frank E. Gaebelein (vol. 5, Grand Rapids: Zondervan, 1991): 1-880 [873]. See also Rendtorff, Canonical Hebrew Bible, 421.

39 See Terence E. Fretheim, 'Nature's Praise of God in the Psalms', Ex Auditu 3 (1987): 16-30 [19-20].

40 'When on high no name was given to heaven, nor below was the netherworld called by name, primeval Apsu was their progenitor, and matrix-Tiamat was she who bore them all' (Enuma Elish, 1.1-4), see Hallo, Context of Scripture, 1: 391. 
else originates. The emphasis in Genesis 1 on creation by God's word also seems to suggest God as the originator of the cosmos. The fact that this is at the same time significantly different from the kind of generation found in Enuma Elish points again to the uniqueness of Israel's God over against the gods in the Babylonian myth.

Evidence that the Old Testament writers were not limited to a single model of creation may also be found in passages that describe God in language reminiscent of the Canaanite El, rather than Baal. Loren Fisher suggests that in Ugaritic mythology there are two kinds of creation: creation by El, the father of the gods, which comes closer to the idea of creatio ex nihilo; and bringing order out of chaos as seen in the Baal myth. Fisher argues that the Old Testament writers reflect the latter, as something 'more meaningful to the Hebrews', ${ }^{41}$ and appears loath to allow that the Old Testament writers might hold both models. He seems to acknowledge that Genesis 1:1-3 might be taken to suggest a different model of creation; but argues that this ought to be interpreted in the light of the more prevalent and 'more meaningful' Baal creation model. ${ }^{42}$ That seems to impose an arbitrary and unnecessary limitation on the text and on the Old Testament view of creation. It must be conceded that the role of $\mathrm{El}$ in creation in Ugaritic texts is not unambiguous. Marvin Pope notes that El is viewed as the progenitor of the gods, rather than the maker of the universe; though he suggests that El may also have been associated with the creation of the cosmos. ${ }^{43}$ John Day points out that 'El is clearly alluded to as the creator of the earth outside the Ugaritic texts'; and though at Ugarit we can only be certain of his role as 'the creator of mankind (and of the gods) ${ }^{44} \mathrm{El}$ is, nonetheless, the most likely candidate for the role of creator of the cosmos. ${ }^{45}$ A possible example of an Old Testament allusion to creation by El, rather than Baal, is Genesis 14:19, where Melchizedek attributes the creation of 'heaven and earth' to El Elyon, which some see as an epithet of $\mathrm{El}^{46}$ though the narrator is quick to

41 Fisher, 'Creation', 321.

42 Fisher, 'Creation', 323.

43 Marvin H. Pope, El in the Ugaritic Texts (Leiden: Brill, 1955): 49-54.

44 Day, God's Conflict, 17, n. 43.

45 See also Levenson, Creation, 9-10.

46 For further discussion of El Elyon, see, e.g. Pope, El, 50-54; G. Levi Della Vida, 'El 'Elyon in Genesis 14:18-20', JBL 63.1 (1944): 1-9. Della Vida suggests that El Elyon in Gen. 14 is the fusion of two Canaanite gods, El, associated with the earth and Elyon who is linked with the heavens. 
identify Melchizedek's god with the God worshipped by Abraham, and also with YHWH. ${ }^{47}$

What then of the chaos in Genesis 1:2? If God is the originator of everything it follows that God must be the originator of that too. But is it conceivable that God would create chaos? Some have argued, indeed, that since chaos represents the opposite of creation, the idea of 'creating chaos' is a contradiction in terms; a logical impossibility. ${ }^{48}$ Thus the creation of chaos seems to raise just as serious a theological difficulty as the idea that chaos, like God, might be pre-existent.

Westermann argues that the discussion of these alternativescreation out of nothing or creation from pre-existent chaos - owes more to later Greek influence and would have been alien to the thinking of the writer of Genesis $1{ }^{49}$ In my view it would certainly have been alien to his purpose. I have argued that the introductory statement in Genesis 1:1 points to God as the sole originator of the cosmos. That seems to be a key theological idea in Genesis 1 (and elsewhere in the Old Testament), which contrasts, markedly and intentionally, with other Ancient Near Eastern creation accounts. However, the fact that creatio ex nihilo is not clearly expressed in the Old Testament suggests that the doctrine per se was of little concern to the Old Testament writers. Similarly, when the idea of chaos is introduced into the Genesis narrative, there is no interest in exploring its origins. In verse 1 the narrator declares that God is the Creator of everything; from verse 3 we see the outworking of that in terms of God's powerful, creative word. However, there is no comparable expression relating to the chaos of

47 In Gen. 14:22 the repetition of Melchizedek's expression, God Most High, Creator of heaven and earth, by Abraham indicates that the narrator wants to show that Melchizedek worshipped the same God as Abraham. It is likely that the slight variation - the inclusion of YHWH in Abraham's expression - is intended to demonstrate, further, that this God is the same as the God that later generations had come to know as YHWH.

48 E.g. Childs, Myth and Reality, 31; von Rad, Genesis, 48; Waltke, 'Creation Account III, 219-20. Some have suggested that Isa. 45:7-I form the light and create darkness, I bring prosperity and create disaster - points to God as the creator of chaos; though this is often seen as being opposed to the theology of Gen. 1; see, e.g. Day, God's Conflict, 55; Levenson, Creation, 124-27; Claus Westermann, Isaiah 40-66 (OTL; London: SCM, 1978): 161-62. C. Stuhlmueller, 'The Theology of Creation in Second Isaias', $C B Q 21$ (1959): 429-46 [448-49, 460-61], argues that this emphasises God's power over everything including chaos. However, cf. Michael Deroche, 'Isaiah XLV 7 and the Creation of Chaos?', VT 42.1 (1992): 11-21. My thesis that Gen. 1:1-2 contains unresolved tension allows the possibility that God is responsible for 'chaos', though Isa. $45: 7$ is the only passage where that may be directly indicated.

49 Westermann, Genesis 1-11, 108-10. 
verse 2. We may assume that God made it out of nothing, or that it was pre-existent, but the text is specific about neither; as Brueggemann notes: "Israel evidences no interest or curiosity in the "stuff of creation". It is simply there'; ${ }^{50}$ he observes, further: 'the very ambiguity of creation from nothing and creation from chaos is a rich expository possibility. We need not choose between them, even as the text does not. Both permit important theological affirmation'. ${ }^{51}$

Rather than engage in a detailed theological debate, Genesis 1:1-2 simply sets these two key ideas alongside one other: that God is the creator of everything; and that creation involves God bringing order out of chaos. Both have important theological trajectories; but the narrative makes no attempt to address their implications or to resolve the tension between them.

It might be argued that the tension in these verses is best resolved by understanding that the chaos in Genesis 1:2 is the result of an initial act of the drama of creation described in Genesis $1: 1 .^{52}$ However, that is to impose logical consistency on the text that may be foreign to the intention of the writer-who seems content to live with unresolved tension. The question of whether they point to creatio ex nihilo or to pre-existent chaos may be of interest to us, but it appears not to have been an issue for the narrator in Genesis 1. As with Old Testament theology in general, we need to be wary of attempting to formulate detailed answers to questions that the Old Testament writers themselves had no interest in asking. It is probably also unwise to attempt to distil precise propositional theological statements from a narrative passage.

There have been several diachronic approaches to this issue. Levenson, for example, sees the creation account in Genesis 1 as 'the result of a long process of tradition that culminates in the Jewish, Christian and Muslim philosophical doctrine of creatio ex nihilo ... a point on the trajectory that runs from the Ancient Near Eastern combat myth to the developed creation theology of the Abrahamic faiths'. ${ }^{53}$

50 Walter Brueggemann, Theology of the Old Testament: Testimony, Dispute, Advocacy (Minneapolis: Augsburg Fortress, 1997): 158-59 [158]; see also Walter Brueggemann, Genesis (Interpretation; Philadelphia: Westminster John Knox Press, 1991): 28-29.

51 Brueggemann, Genesis, 28; see also Stuhlmueller, 'Theology of Creation'; Waltke, OT Theology, 180-81; Waltke, 'Creation Account IV', 338-39.

52 See notes 29, 30, above; see also Routledge, OT Theology, 133-34.

53 Levenson, Creation, 53. 
Westermann discusses the view of Schmidt and others that the creation account in Genesis 1 includes two traditions, creation by word or command, and creation by action, which includes verse 2 . The former is P's own contribution - but he does not see this as the only view of creation and so has allowed other voices to speak. ${ }^{54}$ These approaches may be valid; but they need to be taken alongside synchronic questions. So, for example, Childs suggests that Genesis 1 is a recension by the Priestly writer in which he reworks an earlier idea of creation as the shaping of pre-existent chaos in line with his own theology of God's transcendence. However, Childs also argues that the retention of the awkward reference to chaos in verse 2 does not point to incomplete assimilation, but is deliberate. ${ }^{55}$ This raises the key question of why, in spite of the tension between them, these two views of creation have been allowed to stand side by side within the canonical text.

\section{Key Theological Themes}

\section{3:1 God Created Everything}

The idea of God as sole creator of everything that exists emphasises the distinction between God and the created order. Unlike the Babylonian Ur-deities, who emerge from the primordial sludge, the God of the Old Testament is self-existent and independent of the world. He is transcendent: of a different order of being from what he has created; ${ }^{56}$ and eternal: ${ }^{57}$ God before the primordial events associated with the Creation and God now and forever (Ps. 90:2). ${ }^{58}$

54 Westermann, Genesis 1-11, 82-85. See also Islwyn Blythin, 'A Short Note on Genesis I 2', VT 12 (1962): 120-21; Blythin sees v. 2 as an interpolation intended to introduce the idea of God's continuing power over nature, seen in the mythological imagery of God's control of chaos, into an essentially demythologised account.

55 Childs, Myth and Reality, 39-43; see also, von Rad, Genesis, 50-51.

56 So, for example, Isaiah contrasts the help that the Egyptians, who are mere 'flesh', can offer, with reliance on God, who is 'spirit' (Isa. 31:3; cf. 2 Chr. 32:8).

57 See, e.g. Ps. 90:2: 93:2; Prov. 8:22-27; Isa. 57:15.

58 Weiser notes: 'the eternal being of God warrants that his dominion will last forever' (Psalms, 619); see also, pp. 596-97; Anderson, Psalms 2, 650, 667-68. Commenting on Ps. 90:2, Anderson points to the emphasis on 'the eternal God who, as the creator precedes the created world, and whose majesty can hardly be grasped by his creatures' (Psalms 2, 650). 
Because he is its Creator, everything owes its existence to God and remains dependent on him. ${ }^{59}$ That has implications for God's people who rely on him to sustain them, and for the rest of the created order, which God also sustains and which will eventually come to acknowledge him. ${ }^{60}$ The belief that God created everything points to his absolute authority over all that exists - commanding even the sun, moon and stars ${ }^{61}$ and to a majestic glory that elicits the psalmist's praise and wonder, ${ }^{62}$ and the awe that silences Job's questioning. ${ }^{63}$

God's activity as Creator sets him apart, too, from other gods. He is unique, incomparable $;^{64}$ while the gods of the nations are worthless idols. ${ }^{65}$ Again, this emphasises God's power to deliver and restore his people. And the movement in these verses towards a full expression of monotheism also opens the way to a new understanding of the relationship between God and the non-Israelite nations: in the absence of any other, he is their Creator and he is their God too. ${ }^{66}$

These theological themes are not articulated in abstract, propositional form in the Old Testament; and their full implications are not always developed. Nevertheless they play a vital part in the Old Testament writers' understanding of God as Creator, and of his relationship with his people and his world.

59 E.g. Ps. $104 ; 148$.

60 So, e.g. in Ps. 145:8-9, an expression linked primarily with Israel's covenant relationship with God, in which the (covenant) term hesed is prominent, is applied to the whole of creation. For further discussion see Robin Routledge, 'Mission and Covenant in the Old Testament' in Bible and Mission: a Conversation between Biblical Studies and Missiology, ed. Rollin G. Grams, I. Howard Marshall, Peter F. Penner and Robin Routledge, (Schwarzenfeld: Neufeld Verlag, 2008): 8-41.

61 E.g. Ps. 147:4; 148:1-6.

62 E.g. Ps. $8: 3-5 ; 136 ; 148$.

63 Job 38 .

64 Isa. 40:25-26, cf. vv. 18-20; see also 45:18.

65 E.g. Jer. 10:6-13; 51:17-19; Ps. 96:5.

66 For further discussion of the development of monotheism through the Old Testament and bibliography, see Routledge, OT Theology, 94-100; see also Robert K. Gnuse, No Other Gods: Emergent Monotheism in Israel (JSOTSup, 241; Sheffield: Sheffield Academic Press, 1997); Nathan MacDonald, Deuteronomy and the Meaning of 'Monotheism' (Tubingen: Mohr Siebeck, 2003); Mark S. Smith, The Origins of Biblical Monotheism: Israel's Polytheistic Background and the Ugaritic Texts (Oxford: Oxford University Press, 2001): 135-48; The Early History of God: Yahweh and the Other Deities in Ancient Israel (2nd edn; Grand Rapids: Eerdmans, 2002): 1943. For discussion of the relationship between 'monotheism' and Israel's mission to the nations see, e.g. Christopher J. H. Wright, The Mission of God: Unlocking the Bible's Grand Design (Downers Grove: IVP; Leicester: IVP, 2006): 71-188. 


\section{3:2 In Creation God Brings Order out of Chaos}

In the past, and in some settings today, the idea of God as sole creator of everything that exists (and maybe also of creatio ex nihilo) would not need to be defended. Nowadays, the alternative view that in creation God brings order out of chaos seems to be more widely held. As I have indicated, I do not agree that the latter is to be preferred over the former; nevertheless, the view of creation as the transformation of chaos points to another significant theological trajectory that must be held in tension with the idea that the whole cosmos is the creative work of a transcendent God.

This second model of creation also points to the majesty and glory of God. In Enuma Elish and Baal and the Sea the struggle with chaos monsters results in the affirmation of kingship. And the Chaoskampf motif in the Old Testament is used, similarly, to affirm the power and sovereign authority of God.$^{67}$ In addition, by portraying creation as a process, in which God transforms what is 'formless and empty' into an ordered universe that can be declared very good (Gen. 1:31), the narrator in Genesis 1 also makes affirmations about the created order. ${ }^{68}$

First, chaos rather than nothingness or unbeing is portrayed as the converse of creation. ${ }^{69}$ Genesis 1:2 describes the state of the world without God's transforming power; and in so doing holds up the terrifying possibility of what the world might become again. We see something of that in the rest of Genesis 1-11, and especially in the story of the Flood-where the return of the chaotic waters may be viewed as an 'uncreation'. ${ }^{70}$ This indicates that chaos has not yet been finally removed from God's creation; but, rather, is held in check by God, who may allow it to return as a result of human $\sin ^{71}$ So,

67 E.g. Job 26:7-14; 41:1-11; Pss. 74:12-14; 89:9-13; 104:1.

68 In the material that follows there is some overlap with Routledge, OT Theology, 135-36; Routledge, 'Mission in the Bible', 17.

69 See, e.g. Childs, Myth and Reality, 43; Rendtorff, Canonical Hebrew Bible, 41819.

70 Among other patterns running through Gen. 1-11, Clines notes the 'CreationUncreation-Re-creation' theme; see David J. A. Clines, The Theme of the Pentateuch (JSOTSup, 10; Sheffield: JSOT Press, 1978): 73-76; see also, e.g., B. W. Anderson, Creation to New Creation, 34-36; Fretheim, God and World, 79-83.

71 See, e.g., Anderson, Creation to New Creation, 35-37; Brueggemann, Theology, 534-43; P. C. Craigie, H. Kelley and J. F. Drinkard Jr., Jeremiah 1-25 (WBC, 26; Dallas: Word Books, 1991): 80-82, 112; Fretheim, God and World, 81-82; Levenson, Creation (though see my comments in Routledge, OT Theology, 135, n. 28); Rendtorff, Canonical Hebrew Bible, 418-20. 
Jeremiah likens the judgement coming on Judah to a return to precreation chaos; to a world that is תהו רָבדהו (Jer. 4:23). Isaiah 24 points to a scene of desolation as a result of breaking the everlasting covenant (v. 5) - probably God's covenant with Noah, and through him with the created order. ${ }^{72}$ This brings cosmic instability (vv. 18b-20)including the opening of the floodgates of heaven (recalling the language of the Flood), ${ }^{73}$ and the shaking of the earth's foundations. Zephaniah 1:2-4 also describes God's judgment in terms that both echo the devastation of the Flood (Gen. 6:7) and again point to the reversal of creation. ${ }^{74}$

Second, and more positively, this model of creation gives hope that where chaos may re-emerge, the God who defeated the monsters of the deep in the beginning and brought order out of chaos then, is able to bring restoration and new life to his people in whatever situation they find themselves. In Isaiah 51:9-11, Chaoskampf imagery is closely linked with God's deliverance at the Red Sea, bringing creation and exodus together as one act in the redemptive purposes of God. ${ }^{75}$ This is further applied to the deliverance from exile, which is portrayed as a new and better exodus. ${ }^{76}$ The exile may represent a return to chaos; but, God as Redeemer will transform that chaos, as at the beginning, and

72 For further discussion of a possible 'covenant with creation', see, e.g. Routledge, 'Mission and Covenant', 15-17; Routledge, OT Theology, 164; see also, W. J. Dumbrell, Covenant and Creation (Exeter: Paternoster Press, 1984): 24-26, 32; R. Murray, The Cosmic Covenant: Biblical Themes of Justice and Peace and the Integrity of Creation (London: Sheed \& Ward, 1992); W. Vogels, God's Universal Covenant: A Biblical Study (Ottawa: University of Ottawa Press, 1979).

73 Gen. 7:11; 8:2.

74 See John Goldingay, Old Testament Theology 2: Israel's Faith (Downers Grove: IVP; Milton Keynes: Paternoster, 2006): 307-8; O. Palmer Robertson, The Books of Nahum, Habakkuk and Zephaniah (NICOT; Grand Rapids: Eerdmans, 1991): 257-60. Murray describes Isa. 24 as 'the undoing of creation and its order' (Cosmic Covenant: 19).

75 See Gerhard von Rad, 'The Theological Problem of the Old Testament Doctrine of Creation' in Anderson, Creation, 53-64. God's creative acts frequently stand alongside his saving acts on behalf of his people (e.g. Ps. 33; 136; 148). Scholars have noted the close link between creation and redemption in Isa. 40-55-where God's power as Creator reassures his people of his ability to fulfil his promise to deliver them; see, e.g., Isa. 40:12-14, 21-28; 42:5-9; 45:12-13. For a limited discussion and bibliography, see, Routledge, OT Theology, 136-38; see further, C. Stuhlmueller, Creative Redemption in Deutero-Isaiah (AnBib, 43; Rome: Biblical Institute, 1970); S. Lee, Creation and Redemption in Isaiah 40-55 (Hong Kong: Alliance Bible Seminary, 1995); David M. Gunn, 'Deutero-Isaiah and the Flood', JBL 94 (1975): 493-508.

76 E.g. Isa. 43:16-17; 48:20-21; cf. 52:12. 
bring about the renewal of his people. ${ }^{77}$ And this motif is further applied to the vision of the future, where God's victory over chaos points to the eschatological overthrow of evil and the promise of a new creation. $^{78}$

In my view this link between creation and redemption in which the exodus and return from exile are viewed as creative acts also allows us to see creation as a salvific act - in which God rescues the cosmos from chaos. ${ }^{79}$ This is evident particularly in the deliverance following the Flood, which emphasises God's primary commitment to the created order and may be seen as a pattern for his redemptive dealings with the world. ${ }^{80}$

\section{Conclusion}

Genesis 1:1-2, then, points to two views of creation each with its own important theological trajectory. Despite recent pressure on it, the view


sustainable, but is also probable. This presents God as the sole creator of heaven and earth, and affirms his transcendence and pre-existence. In verse 2, the description of the earth as תדהו רָבדהו and the reference to תוֹ recall the idea of creation as the transformation of primordial chaos found in other Ancient Near Eastern creation myths, and elsewhere in the Old Testament. This emphasises the possibility of the return of chaos, God's ongoing power to bring order and renewal to the

77 Mowinckel argues that God's victory over chaos was re-enacted annually at what he claims was an Enthronement Festival; and this provided the basis for DeuteroIsaiah's message of hope for the people in exile. See S. Mowinckel, He That Cometh (Oxford: Basil Blackwell, 1959): 138-43.

78 E.g. Isa. 27:1. Following Gunkel, Creation and Chaos, this motif is frequently described as Urzeit wird Endzeit; see also, e.g. B. W. Anderson, Creation versus Chaos, 114-15; B. W. Anderson, Creation to New Creation, 34-38, 196-98; John Day, God's Conflict, 82, 141-77; John Day, Yahweh and the Gods and Goddesses of Canaan (JSOTSup, 265; Sheffield: Sheffield Academic Press, 2000): 105-107; Levenson, Creation, 27-28.

79 See, e.g. Routledge, 'Mission and Covenant', 18-20; see also Fisher, 'From Chaos to Cosmos', 191-97; Fretheim, God and World, 109-12; Goldingay, Israel's Gospel, 67; Goldingay, Israel's Faith, 160; James Chukwuma Okoye, Israel and the Nations: A Mission Theology of the Old Testament (Maryknoll, Orbis, 2006): 34; see also Stuhlmueller, 'Theology and Creation', 463-65.

80 The Flood is given explicit redemptive significance in Isa. 54:9-11; see also, e.g. Jer. 33:20-26, where the reference to God's covenant with the day and ... with the night probably alludes to Gen. 8:22, and so, again, to God's commitment to creation embodied within the Noahic covenant. 
lives of his people, and the promise of his final eschatological victory over all that opposes him. The Old Testament writers appear content not to try to resolve the tension between these views. To do so might produce a more logically consistent theology; but it would also diminish its ability to describe all aspects of creation. Here, as elsewhere, unresolved tension is necessary to preserve the richness and the scope of our understanding of God's nature and of his activity in the world. 